\title{
Comment on Chen, J.; Su, Y.; Si, H.; Chen, J. Managerial Areas of Construction and Demolition Waste: A Scientometric Review. Int. J. Environ. Res. Public Health 2018, 15, 2350
}

\author{
Yuh-Shan Ho \\ Trend Research Centre, Asia University, No. 500, Lioufeng Road, Wufeng, Taichung County 41354, Taiwan; \\ ysho@asia.edu.tw; Tel.: +886-4-2332-3456 (ext. 1797); Fax: +886-4-2330-583
}

Received: 9 April 2019; Accepted: 8 May 2019; Published: 23 May 2019

\begin{abstract}
"Managerial areas of construction and demolition waste: A scientometric review" by Chen et al. was recently published in the journal [1]. Most of the related results mentioned in the original paper [1] are unacceptable because of the use of inappropriate search filters. Chen et al. stated in Section 2.1. Data Collection that 'Data for the contribution was extracted from the WoS Core collection database (SCI-EXPANDED, SSCI) in May 2018.' and 'The final search terms included "TS = ("construction waste *" OR "demolition waste *" OR "construction and demolition waste *" OR "CDW" OR "C\&DW") AND TS = ("management" OR "managerial" OR "managing" OR "manage")". The language of the publications was limited to English and document type was limited to articles, and the time span was set to 1975-2018. As a result, 398 bibliographic records were retrieved.'

Searching keywords used in the original paper [1] were inappropriate. "CDW" was used as a searching keyword, however, many of the publications were irrelevant "construction and demolition waste", for instance, cell dry weight (CDW), community disability workers (CDW), Cada Dia Welsh (CDW), cellular dry weight (CDW), collaborative design workshop (CDW), cotton direct-seeded after wheat $(\mathrm{CDW})$, clinical data warehouse $(\mathrm{CDW})$, corrected dry weights (CDW), clipping dry weight (CDW), Changjiang diluted water (CDW), corporate data warehouse (CDW), coarse dead wood (CDW), central data warehouse (CDW), conventional diagnostic work-up (CDW), colonial development and welfare (CDW), circumpolar deep water (CDW), and CPP Ile-de-France II-CDW_2016_0014.

A better way to improve this method would be to search data from SCI-EXPANDED and SSCI (updated on 25 March 2019) by using ("construction waste" or "construction wastes" or "demolition waste" or "demolition wastes" or "C\&DW" or "C\&D waste") and ("management" or "manager" or "managers" or "manage" or "managing" or "managed" or "manageable") as keywords in terms of the topic (including title, abstract, author keywords, and KeyWords Plus) within the publication years between 1975-2018. The limitation was set to the language being only English and the document type being only articles. This method resulted in 496 articles (125\% of 398 articles). From the original paper [1], the authors stated that "document type was limited to articles", however, two reviews "Trend of the research on construction and demolition waste management" [2] and "Quantifying construction and demolition waste: an analytical review" [3] were found in Table 2.

The Web of Science Core Collection is designed for researchers to find published literature, and not for bibliometric studies [4,5]. Therefore, using the Web of Science Core Collection with an accurate bibliometric method is critical for all researchers [4,5]. It was pointed out that the documents searched out by KeyWords Plus were irrelevant to "construction and demolition waste" [6]. Due to biases from the Web of Science Core Collection, Ho's group was the first to propose "front page" (including the article title, the abstract, and the author keywords) as a filter to improve the bibliometric method [7-9]. Furthermore, a more accurate bibliometric method was applied with "front page" as a filter. In all,
\end{abstract}


2591 documents ( $80 \%$ of the 3226 documents) were found including 369 articles ( $74 \%$ of 496 articles) by searching keywords in their "front page" while 127 articles ( $26 \%$ of 496 articles) were likely to be irrelevant to "construction and demolition waste", for example, articles entitled "Removal of cement mortar remains from recycled aggregate using pre-soaking approaches" [10], "Dynamic material flow analysis for Norway's dwelling stock" [11], and "Intrapleural hyperthermic perfusion using distilled water at $48^{\circ} \mathrm{C}$ for malignant pleural effusion" [12]. It is clear that utilizing the "front page" as a filter can avoid introducing unrelated articles for analysis $[7,13]$. In recent years, similar rebuttals have also been published in Environmental Science and Pollution Research [4] and Renewable \& Sustainable Energy Reviews [5].

Furthermore, results by using the "front page" field resulted in 11 highly cited articles with 100 or more total citations from We of Science Core Collection $\left(T C_{2018} \geq 100\right)$ [14], as shown in Table 1.

Table 1. Top 11 highly cited articles.

\begin{tabular}{|c|c|c|c|c|}
\hline Authors & Article Title & Year & Journals & $T C_{2018}$ \\
\hline $\begin{array}{l}\text { Bossink and } \\
\text { Brouwers }\end{array}$ & $\begin{array}{l}\text { Construction waste: Quantification } \\
\text { and source evaluation [18] }\end{array}$ & 2001 & $\begin{array}{l}\text { Journal of Construction } \\
\text { Engineering and Management }\end{array}$ & 176 \\
\hline Poon et al. & $\begin{array}{l}\text { On-site sorting of construction and } \\
\text { demolition waste in Hong Kong [19] }\end{array}$ & 2001 & $\begin{array}{l}\text { Resources Conservation and } \\
\text { Recycling }\end{array}$ & 163 \\
\hline Osmani et al. & $\begin{array}{l}\text { Architects' perspectives on } \\
\text { construction waste reduction by } \\
\text { design [21] }\end{array}$ & 2008 & Waste Management & 123 \\
\hline Kartam et al. & $\begin{array}{l}\text { Environmental management of } \\
\text { construction and demolition waste in } \\
\text { Kuwait [22] }\end{array}$ & 2004 & Waste Management & 105 \\
\hline Bertram et al. & $\begin{array}{l}\text { The contemporary European copper } \\
\text { cycle: waste management } \\
\text { subsystem [23] }\end{array}$ & 2002 & Ecological Economics & 102 \\
\hline
\end{tabular}

The citation indicator, $T C_{2018}$, the total number of citations from Web of Science Core Collection since publication to the end of 2018 [26,27] was also presented in Table 1 . The advantage of $T C_{2018}$ is that they are invariable and ensure repeatability in comparison to the index of citation from the Web of Science [7]. The data were collected on 25 March in 2019. A bias might be obtained as some publications in 2018 have not yet been updated in the Web of Science Core Collection.

Chen et al. used inappropriate searching keywords and methods to publish a bibliometric article in the International Journal of Environmental Research and Public Health, which may result in misleading journal readers. From my perspective, Chen et al. could have provided a more accurate result if they 
had used appropriate searching keywords and method. In addition, using such a limited number of papers for a scientometric review is inappropriate from a statistical point of view.

Funding: This research received no external funding.

Conflicts of Interest: The authors declare no conflicts of interest.

\section{References}

1. Chen, J.G.; Su, Y.Y.; Si, H.Y.; Chen, J.D. Managerial areas of construction and demolition waste: A scientometric review. Int. J. Environ. Res. Public Health 2018, 15, 2350. [CrossRef]

2. Yuan, H.P.; Shen, L.Y. Trend of the research on construction and demolition waste management. Waste Manag. 2011, 31, 670-679. [CrossRef]

3. Wu, Z.Z.; Yu, A.T.W.; Shen, L.Y.; Liu, G.W. Quantifying construction and demolition waste: An analytical review. Waste Manag. 2014, 34, 1683-1692. [CrossRef]

4. Ho, Y.S. Comments on "Mapping the scientific research on non-point source pollution: A bibliometric analysis" by Yang et al. (2017). Environ. Sci. Pollut. Res. 2018, 25, 30737-30738. [CrossRef]

5. Ho, Y.S. Comment on: "A Bibliometric Analysis and Visualization of Medical Big Data Research" Sustainability 2018, 10, 166. Sustainability 2018, 10, 4851. [CrossRef]

6. Fu, H.Z.; Ho, Y.S. Top cited articles in thermodynamic research. J. Eng. Thermophys. 2015, 24, 68-85. [CrossRef]

7. Fu, H.Z.; Wang, M.H.; Ho, Y.S. The most frequently cited adsorption research articles in the Science Citation Index (Expanded). J. Colloid Interface Sci. 2012, 379, 148-156. [CrossRef]

8. Fu, H.Z.; Ho, Y.S. Top cited articles in adsorption research using Y-index. Res. Eval. 2014, 23, 12-20. [CrossRef]

9. Ho, Y.S.; Fu, H.Z. Mapping of metal-organic frameworks publications: A bibliometric analysis. Inorg. Chem. Commun. 2016, 73, 174-182. [CrossRef]

10. Tam, V.W.Y.; Tam, C.M.; Le, K.N. Removal of cement mortar remains from recycled aggregate using pre-soaking approaches. Resour. Conserv. Recycl. 2007, 50, 82-101. [CrossRef]

11. Bergsdal, H.; Brattebø, H.; Bohne, R.A.; Müeller, D.B. Dynamic material flow analysis for Norway's dwelling stock. Build. Res. Inf. 2007, 25, 557-570. [CrossRef]

12. Ba, M.C.; Long, H.; Wang, Y.D.; Tang, Y.Q.; Wu, Y.B.; Zhang, X.L.; Cui, S.Z. Intrapleural hyperthermic perfusion using distilled water at $48^{\circ} \mathrm{C}$ for malignant pleural effusion. J. Cancer Res. Clin. Oncol. 2013, 139, 2005-2012. [CrossRef]

13. Ho, Y.S. Comments on "Past, current and future of biomass energy research: A bibliometric analysis" by Mao et al. (2015). Renew. Sustain. Energy Rev. 2018, 82, 4235-4237. [CrossRef]

14. Hsu, Y.H.E.; Ho, Y.S. Highly cited articles in health care sciences and services field in Science Citation Index Expanded: A bibliometric analysis for 1958-2012. Methods Inf. Med. 2014, 53, 446-458. [CrossRef]

15. Barros, A.I.; Dekker, R.; Scholten, V. A two-level network for recycling sand: A case study. Eur. J. Oper. Res. 1998, 110, 199-214. [CrossRef]

16. Rao, A.; Jha, K.N.; Misra, S. Use of aggregates from recycled construction and demolition waste in concrete. Resour. Conserv. Recycl. 2007, 50, 71-81. [CrossRef]

17. Spengler, T.; Püchert, H.; Penkuhn, T.; Rentz, O. Environmental integrated introduction and recycling management. Eur. J. Oper. Res. 1997, 97, 308-326. [CrossRef]

18. Bossink, B.A.G.; Brouwers, H.J.H. Construction waste: Quantification and source evaluation. J. Constr. Eng. Manag. 1996, 122, 55-60. [CrossRef]

19. Poon, C.S.; Yu, A.T.W.; Ng, L.H. On-site sorting of construction and demolition waste in Hong Kong. Resour. Conserv. Recycl. 2001, 32, 157-172. [CrossRef]

20. Jaillon, L.; Poon, C.S.; Chiang, Y.H. Quantifying the waste reduction potential of using prefabrication in building construction in Hong Kong. Waste Manag. 2009, 29, 309-320. [CrossRef]

21. Osmani, M.; Glass, J.; Price, A.D.F. Architects' perspectives on construction waste reduction by design. Waste Manag. 2008, 28, 1147-1158. [CrossRef] [PubMed]

22. Kartam, N.; Al-Mutairi, N.; Al-Ghusain, I.; Al-Humoud, J. Environmental management of construction and demolition waste in Kuwait. Waste Manag. 2004, 24, 1049-1059. [CrossRef] [PubMed] 
23. Bertram, M.; Graedel, T.E.; Rechberger, H.; Spatari, S. The contemporary European copper cycle: Waste management subsystem. Ecol. Econ. 2002, 42, 43-57. [CrossRef]

24. Ekanayake, L.L.; Ofori, G. Building waste assessment score: Design-based tool. Build. Environ. 2004, 39, 851-861. [CrossRef]

25. Jim, C.Y. Urban soil characteristics and limitations for landscape planting in Hong Kong. Landsc. Urban Plan. 1998, 40, 235-249. [CrossRef]

26. Chuang, K.Y.; Wang, M.H.; Ho, Y.S. High-impact papers presented in the subject category of water resources in the Essential Science Indicators database of the Institute for Scientific Information. Scientometrics 2011, 87, 551-562. [CrossRef]

27. Wang, M.H.; Fu, H.Z.; Ho, Y.S. Comparison of universities' scientific performance using bibliometric indicators. Malays. J. Libr. Inf. Sci. 2011, 11, 1-19.

(C) 2019 by the author. Licensee MDPI, Basel, Switzerland. This article is an open access article distributed under the terms and conditions of the Creative Commons Attribution (CC BY) license (http://creativecommons.org/licenses/by/4.0/). 